\title{
Calculation of the Radiation Dose for Some Hydrobionts of the River Yenisei During the Operation of the Nuclear Fuel Cycle Enterprise - Mining and Chemical Combine, Krasnoyarsk.
}

\author{
LYDIA BONDAREVA, NATALIIA FEDOROVA \\ Federal scientific center of Hygiene named after F.F. Erisman \\ 141014, Mytischi, Semashko street, 2 \\ RUSSIAN FEDERATION
}

\begin{abstract}
The given work considers the accumulation levels of technogenic radionuclides by some components of the river Yenisei near the discharge area of the water containing a big number of technogenic radionuclides, this water being discharged from the Mining and Chemical Combine (MCC). The investigation was carried out during the operation of the nuclear reactor included into the facility of the given enterprise (2006-2009). The content of gamma-emitting technogenic and natural radionuclides was measured. Using the method of gamma spectrometry, a considerable amount of technogenic radionuclides of the activation type $\left({ }^{24} \mathrm{Na}\right.$ - up to $1950 \mathrm{~Bq} \cdot \mathrm{kg}^{-1}{ }^{51} \mathrm{Cr}-$ up to $\left.2860 \mathrm{~Bq} \cdot \mathrm{kg}^{-1}\right)$. were detected in biological objects. Making some assumptions in calculating the dose rate, for the organisms under study the following largest doses were revealed $\left(\mu \mathrm{Gy} \cdot \mathrm{day}^{-1}\right)$ : aquatic plants - up to 39 , fish: grayling - 22,3 and pike - 36,4. These ${ }_{-1}$ values are considerably lower than the accepted radiation dose for aquatic biota which amounts to $10 \mathrm{mGy} \cdot \mathrm{day}^{-1}$.
\end{abstract}

Key-Words: - Rivers, hydrobionts, dose rate, technogenic radionuclides.

Received: December 28, 2019. Revised: May 22, 2020. Re-revised: June 1, 2020. Accepted: June 3, 2020

Published: June 12, $2020 \mathbf{1}$

\section{Introduction}

The River Yenisei is polluted by technogenic radionuclides as a result of the long-term operation of the Mining and Chemical Combine, (MCC, State Corporation Rosatom), which is located on the right bank of the river, $60 \mathrm{~km}$ downstream from the Krasnoyarsk city. Technogenic radionuclides are recorded in all the ecosystem components, including fish fauna [1-3]. Fish fauna is a key link connecting fresh water food chains with the man and it should be considered as a potential carrier of technogenic radionuclides for the population living in the bottomland of the River Yenisei and consuming the fish caught in the river under study.

The assumption concerning the stochastic nonthreshold activity of ionizing radiation lies in the basis of the methods of radiation safety for the man.

There are many radiation risk assessment models used in different countries; however, they do not have identical assumptions, scenarios or calculations. Some models are fairly simple to use and address a narrower scope of scenarios; others are more technically advanced and deal with a wide range of scenarios. Generally, the models use a set of calculations, where the inputs are the parameters for the relevant exposure scenario described by mathematical equations and the output is risk or dose. They are simplified by technical and scientific assumptions to represent a real-world environmental problem.

In several international projects such as EMRAS and EMRAS II launched by International Atomic Energy Agency (IAEA), and well-known scenarios, such as Chernobyl exclusion zone and Fukushima adjacent sea, many frameworks, tools and approaches have been used to make intercomparison of biota dose assessment [3-5]. Among them, RESRAD-Biota, ERICA and R\&D are widely used because they are free and user-friendly.

RESRAD-BIOTA code was primarily developed as a tool for implementing the US DOE graded approach for evaluating radiation doses to biota [5]. It can evaluate radiation exposures of 44 nuclides for specific organisms, including four defaults and eight user-added geometries. Absorbed fraction for specific energy can be calculated using MCNP method and then derive internal and external exposure dose conversion coefficients (DCCs) embedded in code. Bioaccumulation factor (Bp) and distribution coefficient $(\mathrm{Kd})$ values from literatures [6] are used to calculate the whole-organism activity concentration, while inputting site-specific values are allowed in high level assessment. Moreover, the code includes a kinetic-allometric approach [6-9] to estimate the transfer of radionuclides from media to biota bodies and tissues. 
One of the first criteria in regulating the radiation impact on biota was suggested in [6,7], where it was assumed that the dose rate of the chronic exposure providing radiation safety for aquatic biota did not exceed 1-10 mGy·day ${ }^{-1}$. Further, a suggestion was made to use the dose rate value in the range of 1-10 $\mathrm{mGy} \cdot \mathrm{day}^{-1}$ as a safe (threshold) level of radiation impact on biota $[4,6,8]$.

\section{Problem Formulation}

To estimate the radiation dose rate for the aquatic organisms of the River Yenisei from various sources during the operation of the third reactor of the Mining and Chemical Combine, SC Rosatom.

\subsection{Objectives:}

- data collection and analysis concerning the radionuclide content in the studied components of the fresh water ecosystem of the River Yenisei;

- estimation of the radiation dose rate for the aquatic organisms taking into account the radiation sources - water and bottom sediments.

\subsection{Objects and methods.}

The regions with population affected by adverse environmental consequences include the Krasnoyarsk Territory. The Krasnoyarsk Territory region makes up a significant part of the Russian Federation and is a territory which has great potential for the country's economy, including the presence of a fresh water source - the Yenisei River.

The Yenisei is the most full-flowing river in Russia, with a runoff of $624 \mathrm{~km}^{3} /$ year. The average flow rate at the mouth is $19,800 \mathrm{~m}^{3} / \mathrm{s}$, and the maximum is $190,000 \mathrm{~m}^{3} / \mathrm{s}$. By basin area $(2580$ thous. $\mathrm{km}^{2}$ ), the Yenisei takes second place among the rivers of Russia (following the $\mathrm{Ob}$ ) and is seventh among the rivers of the world. The conditional border between Western and Eastern Siberia runs along the Yenisei. Three hydroelectric power plants operate on the Yenisei and the rivers flowing into it. The river water is characterised by high transparency (up to $3 \mathrm{~m}$ ) and weak mineralisation (average value is $54 \mathrm{mg} / \mathrm{L}$ ), and a high concentration of oxygen. The speed and width of the river can vary significantly: 1.5 to $12-15$ $\mathrm{km} / \mathrm{h}$ and $0.2-0.5 \mathrm{~km} / \mathrm{h}$ to $3-5 \mathrm{~km} / \mathrm{h}$. In the upper reaches, the river bed is characterised by boulderpebble sediments, and is replaced by gravel-sand sediments in the middle reaches and by sand-clay sediments in the lower reaches as it flows into the Arctic Ocean.

As a result of the activities of the largest hydroelectric power plants, there is a constant mixing of water layers. This means that, for long distances downstream of the HPP dam, the water temperature almost does not change with the depth of the water. In early July, the water temperature in the area of Krasnoyarsk and $100-150 \mathrm{~km}$ downstream is $\sim 10^{\circ} \mathrm{C}$, and $15-17^{\circ} \mathrm{C}$ in late JulyAugust. The river ecosystem is oligotrophic, with rich river fauna, there being more than 500 species of algae and diatoms in the river water [10].

There is a Mining and Chemical Combine of Rosatom (MCC) on the left bank of the Yenisei, 50 $\mathrm{km}$ downstream from Krasnoyarsk. The MCC includes radiochemical facilities and nuclear reactors. The production facilities of the plant are located on both banks of the Yenisei River, and connected by a tunnel under the river bed. Since 1958, the MCC has used water for cooling industrial reactors to produce weapons-grade $-{ }^{238} \mathrm{Pu}$. The river water, after passing through the cooling system of the reactors, returns to the Yenisei River. Only some part of the radioactive water was collected in the cooling ponds. In the discharges, a significant number of radionuclides have been found, which form due to neutrons activating the admixtures (solid suspensions and dissolved substances) contained in the river water. Two once-through reactors were taken out of service in 1992; therefore, the reactivity level in the effluents discharged from the MCC area has decreased [10]. The last reactor, with a closed circuit, was stopped in 2010.

The research objects were the water samples, bottom sediments and aquatic organisms of the River Yenisei collected in the nearest impact area of MCC in the vicinity of the settlement Atamanovo. The samples were taken during the operation of the third MCC reactor (2006-2009). The sampling site was located near the right bank of the River Yenisei at a distance of $5 \mathrm{~km}$ downstream from the main discharge area of the effluents containing radionuclides.

The collected samples of aquatic plants belonged to three main species of submerged aquatic plants: Potamogeton lucens, Fontinalis antipiretica, Elodea canadensis.

Phytoplankton samples were taken according to the recommendations using the water sampler BM48 with the volume of $1.5 \mathrm{~L}$ of water from the depth of $0.5 \mathrm{~m}$ from the water surface in the photic water layer. The total amount of species was determined as well as their number and biomass. The algal flora included diatom, blue-green, Pyrhophyta and euglena algae. The average number of phytoplankton amounted to $9.82 \pm 2.19$ million cells per liter. 
All the zoobenthos samples were taken using a conventional Eckman dredge. The zoobenthos samples were sieved through a $200 \mu \mathrm{m}$ sieve. The zoobenthos sampling sites corresponded to the sampling sites of the bottom sediments and aquatic plants. After sampling the zoobenthos was carefully washed and instantly frozen in portable freezers for further laboratory study. In the total composition of the zooplankton community 40 species and organism groups were found, including Cladocera19, Copepoda- 5, Rotatoria- 16.

The zooplankton and phytoplankton biomass did not exceed $1 \mathrm{mg} \cdot \mathrm{L}^{-1}$, which, depending on the sampling season, amounted to 7 to $21 \%$ of the deposited suspended substance in the water flow.

In the process of sampling the fish material and its laboratory study the recommendations given in $[4,5]$ were followed. In the fish harvest the amount and species composition were estimated. The number of fish was estimated by the method of direct counting. The species composition was determined using atlas [11].

Due to the fact that in the present work the estimation was made for $\gamma$-emitting radionucludes the specific activity of the collected samples was evaluated using a Canberra gamma-spectrometer (USA) equipped with an ultrapure germanium detector. The $\gamma$-spectra were processed using the software CANBERRAGINIE-PC and GENIE-2000 (USA), allowing one to measure $\gamma$-spectra in the energy range from 30 to $3000 \mathrm{keV}$ with the resolution of $2 \mathrm{keV}$ and to record radionuclides in solid and liquid sample fractions without preliminary preparation. The specific activity of the radionuclides in the aquatic organisms was estimated on the day of sampling. The radionuclide content in the water was estimated after preliminary concentrating using a sorption cartridge developed by Bondareva L.G.

The internal radiation dose $\left(D_{\text {int }}\right)$ was calculated taking into account the radionuclide content in the organisms under study using the dose calculation coefficients [12-15] by the formula:

$$
D_{\text {int }}=\sum_{i} C_{i}^{\text {int }} \cdot \mathrm{DCC}_{\text {int }, i},(1)
$$

where $C_{i}^{\text {int }}$ is the average specific activity of an $i^{\text {th }}$ radionuclide in the organism tissues $\left(\mathrm{Bq} \cdot \mathrm{kg}^{-1}\right.$ of natural humidity); $D C C_{i n t, i}$ is the dose transformation coefficient for the internal radiation taking into account the ratio between the mean specific activity of an $i^{\text {th }}$-radionuclide in the organism under study and the absorbed dose for this organism ( $\mu \mathrm{Gy} \cdot \mathrm{h}^{-1} / \mathrm{Bq} \cdot \mathrm{kg}^{-1}$ of natural humidity).

The absorbed dose rate from the external radiation $\left(D_{e x t}\right)$ was estimated using the formula:

$$
D_{\text {ext }}=D_{\text {wat }}+D_{\text {sed }} \text {, (2) }
$$

where: $D_{\text {wat }}$ is the absorbed dose rate from the water with the suspended substance $\left(\mu \mathrm{Gy} \cdot \mathrm{h}^{-1}\right), D_{\text {sed }}$ is the absorbed dose rate from the bottom sediments $\left(\mu \mathrm{Gy} \cdot \mathrm{h}^{-1}\right)$. The absorbed dose rate from the water with the suspended substance was estimated using the formula:

$$
D_{\text {wat }}=\sum_{i} C_{i}^{\text {wat }} \times \mathrm{DCC}_{\text {ext }, i} \text { (3) }
$$

where $C_{i}^{\text {wat }}$ is the average activity of an $i^{\text {th }}$ radionuclide in the water $\left(\mathrm{Bq} \cdot 1^{-1}\right) ; D C C_{e x t, i}$ is the dose transformation coefficient for the external radiation taking into account the ratio between the average specific activity of an $i$-th radionuclide in the environment (the water including the suspended substances) and that of the absorbed dose for this organism $\left(\mu \mathrm{Gy} \cdot \mathrm{h}^{-1} / \mathrm{Bq} \cdot \mathrm{kg}^{-1}\right.$ of natural humidity).

The total absorbed dose rate $\left(D_{\text {total }}\right)$ was estimated as a sum of the internal and external doses:

$$
D_{\text {total }}=D_{\text {ext }}+D_{\text {int }},(4)
$$

where Dext is the total external absorbed dose $\left(\mu \mathrm{Gy} \cdot \mathrm{h}^{-1}\right) ; D_{\text {int }}$ is the total internal absorbed dose $\left(\mu \mathrm{Gy} \cdot \mathrm{h}^{-1}\right)$.

The error of the dose loading estimates did not exceed $30 \%$.

Statistical analyses were performed using $\mathrm{R}$ version 3.1.2. After satisfying the assumptions of the normal distribution of the residuals, generalized linear models were used. If the normality of the residuals was not respected, a Kruskal-Wallis rank test was applied. When significant, a Wilcoxon rank test and a Bonferroni correction of the $\alpha$ error were performed. Pearson correlation tests were performed.

\section{Problem Solution}

Multiple chemical parameters were measured to assess the presence of potential confounding abiotic factors in each lake during all sampling sessions.

Table 1 presents the data concerning the radionuclide content in the surface layer of the bottom sediments collected at the sampling site for water and biological objects.

As is seen from the presented results the following radionuclides of activation origin entered the water of the River Yenisei: ${ }^{24} \mathrm{Na},{ }^{46} \mathrm{Sc},{ }^{51} \mathrm{Cr}$, ${ }^{54} \mathrm{Mn},{ }^{58} \mathrm{Co}$ etc.

The authors obtained their own data concerning the radionuclide content in the aquatic plants under study (Table. 2), as well as in the phyto- and zooplankton and fish (Table. 3). 
Table 1. Radionuclide content in the water and bottom sediments of the River Yenisei, $\mathrm{Bq} \cdot \mathrm{kg}^{-1}$.

\begin{tabular}{|c|c|c|c|c|c|}
\hline \multicolumn{6}{|c|}{ water } \\
\hline${ }^{24} \mathrm{Na}$ & ${ }^{46} \mathrm{Sc}$ & ${ }^{51} \mathrm{Cr}$ & ${ }^{58} \mathrm{Co}$ & ${ }^{60} \mathrm{Co}$ & ${ }^{65} \mathrm{Zn}$ \\
\hline 92.4 & $0.14 \pm$ & $0.4 \pm$ & $0.07 \pm$ & $0.14 \pm$ & $0.65 \pm$ \\
\pm 2.5 & 0.02 & 0.1 & 0.02 & 0.02 & 0.37 \\
\hline${ }^{76} \mathrm{As}$ & ${ }^{106} \mathrm{Ru}$ & ${ }^{137} \mathrm{Cs}$ & ${ }^{140} \mathrm{La}$ & ${ }^{152} \mathrm{Eu}$ & ${ }^{239} \mathrm{~Np}$ \\
\hline 0.14 & $0.6 \pm$ & $0.12 \pm$ & $0.16 \pm$ & $0.06 \pm$ & $0.34 \pm$ \\
\pm 0.1 & 0.3 & 0.06 & 0.03 & 0.02 & 0.04 \\
\hline \multicolumn{6}{|c|}{ sediment } \\
\hline${ }^{40} \mathrm{~K}$ & ${ }^{60} \mathrm{Co}$ & ${ }^{137} \mathrm{Cs}$ & ${ }^{152} \mathrm{Eu}$ & ${ }^{154} \mathrm{Eu} /$ & ${ }^{241} \mathrm{Am}$ \\
\hline${ }^{466 \pm}$ & $266 \pm$ & $1311 \pm$ & $637 \pm 1$ & $130 \pm 5 /$ & $38 \pm 7$ \\
36 & 11 & 67 & 3 & $29 \pm 3$ & \\
\hline
\end{tabular}

Table 2. Radionuclide content $\left(\mathrm{Bq} \cdot \mathrm{kg}^{-1}\right)$ in aquatic plants of the River Yenisei, which were taken near the settlement Atamanovo (5 $\mathrm{km}$ from the discharge area of MCC)

\begin{tabular}{|c|c|c|c|c|c|}
\hline \multicolumn{6}{|c|}{ Radionuclide content, $\mathrm{Bq} \cdot \mathrm{kg}^{-1}(+/-, \%)$} \\
\hline \multicolumn{6}{|c|}{ Fontinalis antipyretica } \\
\hline${ }^{24} \mathrm{Na}$ & ${ }^{46} \mathrm{Sc}$ & ${ }^{51} \mathrm{Cr}$ & ${ }^{54} \mathrm{Mn}$ & ${ }^{58} \mathrm{Co}$ & ${ }^{59} \mathrm{Fe}$ \\
\hline $\begin{array}{l}1950 \\
(22)\end{array}$ & $90(6)$ & $\begin{array}{c}2680 \\
(16)\end{array}$ & $\begin{array}{c}50 \\
(11)\end{array}$ & $\begin{array}{l}90 \\
(9)\end{array}$ & $\begin{array}{c}40 \\
(13)\end{array}$ \\
\hline${ }^{60} \mathrm{Co}$ & ${ }^{65} \mathrm{Zn}$ & ${ }^{76} \mathrm{As}$ & ${ }^{95} \mathrm{Zr}$ & ${ }^{95} \mathrm{Nb}$ & $\frac{103 \mathrm{Ru}}{10 \mathrm{u}}$ \\
\hline $420(4)$ & $540(6)$ & $340(35)$ & $\begin{array}{c}6 \\
(17)\end{array}$ & $30(19)$ & $\begin{array}{c}13 \\
(27)\end{array}$ \\
\hline${ }^{106} \mathrm{Ru}$ & ${ }^{131} \mathrm{I}$ & ${ }^{134} \mathrm{Cs}$ & ${ }^{137} \mathrm{Cs}$ & ${ }^{140} \mathrm{Ba}$ & ${ }^{140} \mathrm{La}$ \\
\hline $7(30)$ & $\begin{array}{c}21 \\
(26)\end{array}$ & $1,5(38)$ & $\begin{array}{l}100 \\
(9)\end{array}$ & $70(23)$ & $60(9)$ \\
\hline${ }^{141} \mathrm{Ce}$ & ${ }^{144} \mathrm{Ce}$ & ${ }^{152} \mathrm{Eu}$ & ${ }^{154} \mathrm{Eu}$ & ${ }^{155} \mathrm{Eu}$ & ${ }^{239} \mathrm{~Np}$ \\
\hline $40(9)$ & $\begin{array}{c}25 \\
(24) \\
\end{array}$ & $23(9)$ & $7(8)$ & $4(25)$ & $800(3)$ \\
\hline \multicolumn{6}{|c|}{ Elodea canadensis } \\
\hline${ }^{24} \mathrm{Na}$ & ${ }^{46} \mathrm{Sc}$ & ${ }^{51} \mathrm{Cr}$ & ${ }^{54} \mathrm{Mn}$ & ${ }^{58} \mathrm{Co}$ & ${ }^{59} \mathrm{Fe}$ \\
\hline $\begin{array}{l}1250 \\
(20)\end{array}$ & $40(6)$ & $\begin{array}{c}1800 \\
(7)\end{array}$ & $\begin{array}{l}45 \\
(6)\end{array}$ & $70(6)$ & $24(12)$ \\
\hline${ }^{60} \mathrm{Co}$ & ${ }^{65} \mathrm{Zn}$ & ${ }^{76} \mathrm{As}$ & ${ }^{95} \mathrm{Zr}$ & ${ }^{95} \mathrm{Nb}$ & ${ }^{103} \mathrm{Ru}$ \\
\hline $\begin{array}{l}330 \\
\text { (4) }\end{array}$ & $\begin{array}{c}290 \\
(6)\end{array}$ & - & $\begin{array}{c}3 \\
(38)\end{array}$ & $23(14)$ & $10(17)$ \\
\hline${ }^{106} \mathrm{Ru}$ & ${ }^{131} \mathrm{I}$ & ${ }^{134} \mathrm{Cs}$ & ${ }^{137} \mathrm{Cs}$ & ${ }^{140} \mathrm{Ba}$ & ${ }^{140} \mathrm{La}$ \\
\hline $\begin{array}{c}14 \\
(17) \\
\end{array}$ & $\begin{array}{c}10 \\
(27)\end{array}$ & $1,2(16)$ & $55(7)$ & & - \\
\hline${ }^{141} \mathrm{Ce}$ & ${ }^{144} \mathrm{Ce}$ & ${ }^{152} \mathrm{Eu}$ & ${ }^{154} \mathrm{Eu}$ & ${ }^{155} \mathrm{Eu}$ & ${ }^{239} \mathrm{~Np}$ \\
\hline $\begin{array}{c}50 \\
(13)\end{array}$ & $\begin{array}{c}15 \\
(26)\end{array}$ & $12(13)$ & $3(9)$ & $1,7(18)$ & $370(8)$ \\
\hline \multicolumn{6}{|c|}{ Potamogeton lucens } \\
\hline${ }^{24} \mathrm{Na}$ & ${ }^{46} \mathrm{Sc}$ & ${ }^{51} \mathrm{Cr}$ & ${ }^{54} \mathrm{Mn}$ & ${ }^{58} \mathrm{Co}$ & ${ }^{59} \mathrm{Fe}$ \\
\hline $\begin{array}{l}800 \\
(30)\end{array}$ & $\begin{array}{l}310 \\
(5)\end{array}$ & $\begin{array}{c}1970 \\
(16)\end{array}$ & $\begin{array}{l}80 \\
(9)\end{array}$ & $120(9)$ & $78(7)$ \\
\hline${ }^{60} \mathrm{Co}$ & ${ }^{65} \mathrm{Zn}$ & ${ }^{76} \mathrm{As}$ & ${ }^{95} \mathrm{Zr}$ & ${ }^{95} \mathrm{Nb}$ & ${ }^{103} \mathrm{Ru}$ \\
\hline $\begin{array}{l}790 \\
(4)\end{array}$ & $\begin{array}{c}330 \\
(6)\end{array}$ & $\begin{array}{l}330 \\
(22) \\
\end{array}$ & $\begin{array}{c}17 \\
(20) \\
\end{array}$ & $38(17)$ & $21(24)$ \\
\hline${ }^{106} \mathrm{Ru}$ & ${ }^{131} \mathrm{I}$ & ${ }^{134} \mathrm{Cs}$ & ${ }^{137} \mathrm{Cs}$ & ${ }^{140} \mathrm{Ba}$ & ${ }^{140} \mathrm{La}$ \\
\hline $\begin{array}{c}22 \\
(22)\end{array}$ & $\begin{array}{c}35 \\
(24)\end{array}$ & $8.4(22)$ & $\begin{array}{c}350 \\
(8)\end{array}$ & $85(17)$ & $106(7)$ \\
\hline${ }^{141} \mathrm{Ce}$ & $\frac{144}{140}$ & ${ }^{152} \mathrm{Eu}$ & ${ }^{154} \mathrm{Eu}$ & ${ }^{155} \mathrm{Eu}$ & ${ }^{239} \mathrm{~Np}$ \\
\hline $85(8)$ & $80(15)$ & $68(8)$ & $16(8)$ & $4(20)$ & 1490(3) \\
\hline
\end{tabular}

Table 3. Radionuclide content $\left(\mathrm{Bq} \cdot \mathrm{kg}^{-1}\right)$ in phytoand zooplankton and fish of the River Yenisei, which were taken near the settlement Atamanovo (5 $\mathrm{km}$ from the discharge area of MCC)

\begin{tabular}{|c|c|c|c|c|}
\hline \multicolumn{5}{|c|}{ Radionuclide content, $\mathrm{Bq} \cdot \mathrm{kg}^{-1}(+/-, \%)$} \\
\hline \multirow[b]{2}{*}{ 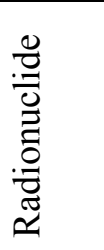 } & \multirow[b]{2}{*}{ 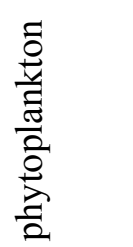 } & \multirow[b]{2}{*}{ 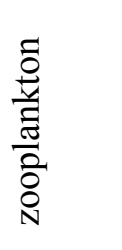 } & \multicolumn{2}{|c|}{ fish } \\
\hline & & & $\begin{array}{c}\text { Thymallus } \\
\text { arcticus } \\
\text { Pallas }\end{array}$ & $\begin{array}{c}\text { pike } \\
\text { Esox } \\
\text { Lucius }\end{array}$ \\
\hline${ }^{24} \mathrm{Na}$ & $\begin{array}{l}478 \\
(23)\end{array}$ & $67(12)$ & $89(17)$ & $\begin{array}{l}105 \\
\text { (34) }\end{array}$ \\
\hline${ }^{40} \mathrm{~K}$ & $\begin{array}{l}27 \\
(9)\end{array}$ & $\begin{array}{l}340 \\
(13)\end{array}$ & $\begin{array}{l}127 \\
(8)\end{array}$ & $\begin{array}{l}374 \\
(19)\end{array}$ \\
\hline${ }^{46} \mathrm{Sc}$ & - & $97(48)$ & - & - \\
\hline${ }^{51} \mathrm{Cr}$ & $\begin{array}{c}1873 \\
(24)\end{array}$ & $\begin{array}{c}2227 \\
(11)\end{array}$ & $\begin{array}{c}1794 \\
(17)\end{array}$ & $\begin{array}{c}2584 \\
(13)\end{array}$ \\
\hline${ }^{54} \mathrm{Mn}$ & - & $21(32)$ & - & - \\
\hline${ }^{60} \mathrm{Co}$ & $7.4(3)$ & $80(5)$ & - & - \\
\hline${ }^{65} \mathrm{Zn}$ & $5.8(5)$ & $120(8)$ & $2.3(15)$ & $6.3(12)$ \\
\hline${ }^{137} \mathrm{Cs}$ & $5.6(2)$ & $80(7)$ & $71(10)$ & $\begin{array}{l}112 \\
(15)\end{array}$ \\
\hline${ }^{152} \mathrm{Eu}$ & $1.9(14)$ & $14(21)$ & $21(12)$ & $34(11)$ \\
\hline
\end{tabular}

The following technogenic activation radionuclides were detected in the biota samples: ${ }^{51} \mathrm{Cr}\left(\mathrm{T}_{1 / 2}=27.8\right.$ days $),{ }^{54} \mathrm{Mn}\left(\mathrm{T}_{1 / 2}=312.3\right.$ days, ${ }^{58} \mathrm{Co}$ $\left(\mathrm{T}_{1 / 2}=70.82\right.$ days $),{ }^{60} \mathrm{Co}\left(\mathrm{T}_{1 / 2}=5.27\right.$ years $),{ }^{65} \mathrm{Zn}$ $\left(\mathrm{T}_{1 / 2}=243.9\right.$ days $),{ }^{144} \mathrm{Ce}\left(\mathrm{T}_{1 / 2}=284.89\right.$ days $),{ }^{152} \mathrm{Eu}$ $\left(\mathrm{T}_{1 / 2}=13.5\right.$ years $)$ as well as the product of nuclear decay ${ }^{137} \mathrm{Cs}\left(\mathrm{T}_{1 / 2}=30.1\right.$ years $)$.

During the period of the nuclear reactor operation, high radioactivity of short-lived radionulides $\left({ }^{24} \mathrm{Na},{ }^{51} \mathrm{Cr},{ }^{239} \mathrm{~Np}\right)$ was observed in all the studied organisms (Table 2, 3).

In all the biological samples, taken upstream from the discharge area of MCC only technogenic ${ }^{137} \mathrm{Cs}$ was detected, its content corresponding to the background values for the region under study $(\sim 70$ $\left.\mathrm{Bq} \cdot \mathrm{kg}^{-1}\right)$, as well as natural radionuclides ${ }^{40} \mathrm{~K}$ and ${ }^{7} \mathrm{Be}$.

\subsection{Estimation of the total radiation doses of hydrobionts in the River Yenisei}

When estimating the dose rates of gammaradiation sources it is important to take into account both the size of a hydrobiont and its geometry. If considering phytoplankton and zooplankton the energy is scattered outside the hydrobionts due to their small size. Thus, the contribution of this type of radiation of the given objects will not be taken into account.

For calculation of internal exposure for aquatic organisms, radionuclides were assumed to be 
distributed uniformly in the organisms; in each case the tissue density was assumed to be unity $[16,17]$. The shape and size of an organism (generally in terms of a mean geometrical factor, g) must be considered for calculation of the absorbed dose rate from gamma radiation [16, 17] The following default values for the geometric sizes of organisms were provided for dose calculation for fish: cylinder $50 \mathrm{~cm}$ in length and $10 \mathrm{~cm}$ in diameter, $\mathrm{g}=41 \mathrm{~cm}$. Specific geometric factors for biota are as follows: pike 1 year of age, $g=23 \mathrm{~cm}$; pike 5 year of age, $g$ $=71 \mathrm{~cm}$; Thymallus arcticus Pallas 1 year of age, $\mathrm{g}$ $=31 \mathrm{~cm}$; Thymallus arcticus Pallas $5 \mathrm{y}$ of age, $\mathrm{g}=$ $75 \mathrm{~cm} \mathrm{[16].}$

The external radiation sources for hydrobionts are water and bottom sediments. Then, the dose rate for the water can be estimated by the formulas for an infinitely extended source and the bottom sediments can be presented as a unit of infinite thickness and extension [16].

Due to the peculiarities of the physical features of ionizing radiation of different types, the main contribution to the external radiation dose rate is made by $\gamma$-radiation sources. Since the size and structure of the studied hydrobionts are very small as compared to the thickness of the water flow and layer of bottom sediments, the processes of absorption and scattering of the radiation energy of gamma quanta can be neglected. Accordingly, the radiation dose rate from external sources can be equal for microalgae (phytoplankton and zooplankton), for macrophytes and fish, which are at the same distance from the radiation source.

To estimate the external radiation dose rate for hydrobionts, use was made of our own data on the content of radionuclides detected in the water and bottom sediments (Table 1). The estimation results of the radiation dose rate for hydrobionts and radionuclides present in the water and bottom sediments are given in Table 4.

The results obtained reveal that the main contribution into the dose rate of external radiation from radionuclides present in the water is made by the activation radionuclide ${ }^{24} \mathrm{Na}$.

The proportion of nuclides making dose contribution depends primarily on their existence in effluent. Our result shows the major radionuclides are ${ }^{137} \mathrm{Cs}-41.77 \%,{ }^{152} \mathrm{Eu}-30.00 \%$ and ${ }^{60} \mathrm{Co}-$ $27.31 \%$, for botom sediments.

The contribution of the natural radionuclide ${ }^{40} \mathrm{~K}$ into the total radiation dose rate does not exceed 10 $\%$ for the water and $\sim 1 \%$ for the bottom sediments.

When analyzing the obtained estimates of the hydrobiont radiation doses from the radionuclides present in the bottom sediments (Table 4), it was found that in this case the dose rate exceeds the dose rate from the radionuclides present in the water. Moreover, the main contribution here is made by techogenic radionuclides.

Table 4. External radiation dose rate for hydrobionts from the radionuclides contained in the river water and bottom sediments $\left(P, \mu \mathrm{Gy} \cdot \mathrm{day}^{-1}\right)$

\begin{tabular}{|c|c|c|c|c|}
\hline \multicolumn{5}{|c|}{ Radionuclides } \\
\hline \multicolumn{5}{|c|}{$\boldsymbol{P}_{\text {water }}$} \\
\hline${ }^{40} \mathrm{~K}$ & ${ }^{24} \mathrm{Na}$ & ${ }^{51} \mathrm{Cr}$ & ${ }^{54} \mathrm{Mn}$ & ${ }^{59} \mathrm{Fe}$ \\
\hline 0.021 & 0.169 & 0.0002 & 0.001 & 0.004 \\
\hline${ }^{60} \mathrm{Co}$ & ${ }^{65} \mathrm{Zn}$ & ${ }^{76} \mathrm{As}$ & ${ }^{137} \mathrm{Cs}$ & ${ }^{152} \mathrm{Eu}$ \\
\hline 0.0003 & 0.001 & 0.004 & 0.0002 & - \\
\hline \multicolumn{5}{|c|}{$\boldsymbol{\Gamma}=0.201$} \\
\hline \multicolumn{5}{|c|}{$\boldsymbol{P}_{\text {sediment }}$} \\
\hline${ }^{40} \mathrm{~K}$ & ${ }^{60} \mathrm{Co}$ & ${ }^{137} \mathrm{Cs}$ & ${ }^{152} \mathrm{Eu}$ & $\mathbf{\Sigma P}$ \\
\hline 0.5 & 7.1 & 10.6 & 7.8 & 26.0 \\
\hline
\end{tabular}

However, taking into account the fact that the main biomass of the studied macrophytes grows at a distance of 50-100 $\mathrm{cm}$ from the bottom surface, the radiation dose rate from the radionuclides present in the bottom sediments can be compared with the radiation dose rate from the water.

As regards phytoplankton and zooplankton, there are no distinct boundaries of their distribution in the water column, i.e. they can equally be found near the surface of bottom sediments and at any other distance from the surface. When estimating the radiation dose rate an assumption was made on the exponential character of the decrease in the radiation dose with the increasing distance from the bottom. Then, the average radiation dose rate of phyto- and zooplankton from the radionuclides found in the bottom sediments was equal to 5.2 $\mu \mathrm{Gy} \cdot$ day $^{-1}$, with their random distribution in the water column.

Dose loading on the fish organism is formed by external radiation - from water and bottom sediments, and by internal one - from incorporated radionuclides.

To estimate the dose of internal radiation absorbed during a year by fish it is enough to have the data on the average annual radionuclide content in the organisms of different species. The external radiation from the water is estimated using the average annual concentration of radionuclides in the water. In the case of the variation in the specific content of a radionuclide in the organism or water, use was made of the average concentration for the time period when the change in the concentration can be neglected, then, the dose acquired by the organism during these periods is summed up. 
The absorbed dose also depends on the migration behavior of fish [18]. The fish behavior is conditioned by a number of factors. The feeding behavior of fish depends on the diet content and location of food items relative to the bottom sediments $[18,19]$. This significantly influences the vertical distribution of fish of different species in the water bodies, and, consequently, affects the value of the geometrical factor of the fish radiation $[18,19]$.

Evaluation was made of the content of several radionuclides $\left({ }^{24} \mathrm{Na},{ }^{40} \mathrm{~K},{ }^{51} \mathrm{Cr},{ }^{54} \mathrm{Mn},{ }^{60} \mathrm{Co},{ }^{65} \mathrm{Zn}\right.$, $\left.{ }^{137} \mathrm{Cs},{ }^{152} \mathrm{Eu}\right)$ in grayling Thymallus arcticus Pallas, who fed on zoobenthos and plants and in a typical predator - pike Esox Lucius (Table 3). The given fish species do not migrate and, consequently, the influence of radionuclides can be considered to be a chronicle one.

The results obtained show that in the studied fish the content of the detected radionuclides does not exceed the accepted standards. The geometrical factor and internal radiation dose rate were estimated for the fish in accordance with the recommendations provided in $[12,17]$. The total dose rate for grayling was $22.3 \mu \mathrm{Gy} \cdot$ day $^{-1}$, and for pike $-36.4 \mu \mathrm{Gy} \cdot$ day $^{-1}$.

The resulting summed radiation dose rate for the studied hydrobionts of the River Yenisei from the external and internal radiation sources is presented in Table 5.

Table 5. Total radiation dose rate of the aquatic organisms in the River Yenisei

\begin{tabular}{|c|c|c|c|c|c|}
\hline & \multicolumn{5}{|c|}{$\begin{array}{c}\text { Total radiation dose rate } \\
\left(P, \mu \mathrm{Gy} \cdot \text { day }^{-1}\right)\end{array}$} \\
\hline & \multicolumn{2}{|c|}{$\begin{array}{l}\text { external } \\
\text { radiation }\end{array}$} & \multicolumn{2}{|c|}{$\begin{array}{l}\text { internal } \\
\text { radiation }\end{array}$} & \multirow{2}{*}{$\begin{array}{c}\text { Total } \\
\text { radiation } \\
\text { dose }\end{array}$} \\
\hline & 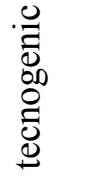 & 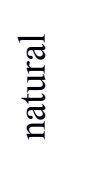 & $\begin{array}{l}\bar{\Phi} \\
\frac{\pi}{3} \\
3\end{array}$ & 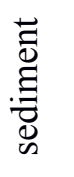 & \\
\hline $\begin{array}{l}\text { Potamogeton } \\
\text { lucens }\end{array}$ & 27.1 & 4.6 & 0.2 & 0.2 & 32.1 \\
\hline $\begin{array}{c}\text { Elodea } \\
\text { canadensis }\end{array}$ & 23.0 & 5.3 & 0.2 & 0.2 & 27.1 \\
\hline $\begin{array}{c}\text { Fontinalis } \\
\text { antipyretica }\end{array}$ & 34.9 & 3.7 & 0.2 & 0.2 & 39.0 \\
\hline phytoplankton & 3.1 & 0.03 & 0.2 & 5.2 & 8.5 \\
\hline zooplankton & 1.1 & 0.02 & 0.2 & 5.2 & 6.5 \\
\hline $\begin{array}{c}\text { Thymallus } \\
\text { arcticus } \\
\text { Pallas }\end{array}$ & 15.9 & 1.01 & 0.2 & 5.2 & 22.3 \\
\hline Esox Lucius & 27.4 & 3.6 & 0.2 & 5.2 & 36.4 \\
\hline
\end{tabular}

Analysis of the results presented in Table 5 shows that for internal exposure, the dose rate of artificial radiation is an order of magnitude higher than the dose rate of natural radiation in most of aquatic organisms.

Among aquatic organisms, the highest dose rate is received by aquatic plants (up to $39 \mu \mathrm{Gy} \cdot \mathrm{day}^{-1}$ ). As the water moss (Fontinalis antipyretica) has the highest capacity to accumulate artificial radionuclides, it accumulates the largest artificial exposure dose among the study aquatic organisms.

Comparing our data with the data for a marine ecosystem, we can see that the total dose received by the organisms of the Yenisei River is an order of magnitude larger than the exposure doses to biota of the Arctic and the Pacific seas [3, 5, 9]. The marine biota receives most of its radiation dose (up to $99 \%$ ) from natural radionuclides. Our investigations and calculations indicate that the coolant of the third MCC reactor, which is still released into the Yenisei, is the main source of radioactive contamination of aquatic organisms. Gammaspectrometry has registered more than 20 artificial radionuclides in the biomass of aquatic plants, In addition to short-lived radionuclides, aquatic plants also contain artificial long-lived radionuclides, including plutonium isotopes. Water plants can take up the long-lived radionuclides both from the effluents of the Radiochemical Plant at the Combine and from sediments in their growth area. The freshwater diatomic plankton also contain artificial radionuclides.

Among aquatic organisms, the highest dose rate is received by aquatic plants (up to $39 \mu \mathrm{Gy} \cdot \mathrm{day}^{-1}$ ) for the water moss (Fontinalis antipyretica). For most aquatic organisms under study, the dose received from the artificial irradiation is an order of magnitude higher than the dose received from natural irradiation.

We may conclude that aquatic organisms of the Yenisei River can accumulate large amounts of various radionuclides and this should be taken into account in monitoring the migration of radionuclides along food chains.

It should be noted that in the current period after the shutdown of the last reactor of MCC in 2010 the water contributes less than $0,1 \%$ into the total radiation dose in the River Yenisei. The contribution of the incorporated radionuclides into the total radiation dose of non-predatory fish amounts to 1$14 \%$, and that of predatory ones is $2-24 \%$. Thus, the contribution of water into the total radiation dose acquired during a year by mature representatives of the fish fauna of the River Yenisei is negligibly small. 


\section{Conclusion}

1. The analysis of the water, bottom sediments, several hydrobionts sampled during the operation of the Mining and Chemical Combine SC Rosatom revealed a significant list of technogenic radionuclides $\left({ }^{24} \mathrm{Na},{ }^{46} \mathrm{Sc},{ }^{51} \mathrm{Cr},{ }^{54} \mathrm{Mn},{ }^{58} \mathrm{Co}\right.$ etc. $)$ of different origin (activation or fission radionuclides), which have different half-life periods (lasting for hours, days, years) and distinct physico-chemical properties.

2. Based on the available recommendations the radiation dose rate was estimated for phyto- and zooplankton, several aquatic plants and two species of commercial fish: plankton-eater - grayling, and predator - pike. It was shown that a high portion of the radiation dose rate was due to technogenic radionuclides while the natural ones (represented mostly by ${ }^{40} \mathrm{~K}$ ) result in no more than $5.3 \%$.

3. The obtained radiation doses for the hydrobionts of the River Yenisei during the operation period of the third MCC nuclear reactor are considerably lower than the radiation dose for aquatic biota, namely $10 \mathrm{mGy} \cdot \mathrm{day}^{-1}$.

\section{References:}

\section{References:}

[1] Bondareva L. The relationship of mineral and geochemical composition to artificial radionuclide partitioning in Yenisei River sediments downstream from Krasnoyarsk, Environmental Monitoring and Assessment, V. 184, No. 6, 2012, pp. 3831-3847.

[2] Zotina T.A., Trofimova E.A., Bolsunovsky A.Ya. Artificial radionuclides in fish fauna of the Yenisei River in the vicinity of the Minimg-andChemical Combine (Siberia, Russia), Radioprotection, Vol. 46, No. 6, 2011, pp. 75-78.

[3] Bondareva L., Fedorova N., Rakitskii V. Mathematical calculation of the mass transport in water flow of the River Yenisei in the impact zone of the mining and chemical combine, Environmental Pollution and Protection, V.2, No 1, 2017, pp. 6-14.

[4] Till J.E., Meyer. H.R. Radiological assessment: A textbook on environmental dose analysis. NUREG/CR-3332. WASHINGTON, D.C.: USNRC, 1983.

[5] Handbook for assessment of the exposure of biota to ionising radiation from radionuclides in the environment / Ed. by J. Brown, P. Strand, Al. Hosseini. - Project within the EC 5th Framework Programme, Contract № FIGE-CT-2000-00102. Framework for Assessment of Environmental Impact, 2003.

[6] IAEA. Sediment Distribution Coefficients and Concentration Factors for Biota in the Marine
Environment, Technical Report Series No. 422. Vienna: IAEA, 2004.

[7] IAEA. Generic Models for Use in Assessing the Impact of Discharges of Radioactive Substances to the Environment, Safety Reports Series No. 19. Vienna: IAEA, 2001.

[8] A Graded Approach for Evaluating Radiation Doses to Aquatic and Terrestrial Biota. DOE-STD-1153-2002, 2002.

[9] Brown J.E., Alfonso B., Avila R., The ERICA tool. Journal of Environmental Radioactivity, V. 99, N 9, 2008, pp. 1371-1383.

[10] Bolsunovsky A., Bondareva L. Actinides and other radionuclides in sediments and submerged plants of the Yenisei River. Journal of Alloys and Compounds. V. 444-445, 2007, pp. 495-499.

[11] Freshwater fishes of Russia, Moscow, Nauka, 2002 (In Russian)

[12] Soldat J.K., Robinson N.M., Buker D.A. Models and computer codes for evalutiong environmental radiation doses BNWL-1754. Report Pacific Northwest National Laboratory. Richland, Washington, 1974.

[13] Effects of Ionizing Radiation on Aquatic Organisms. NCRP. Report No. 109, 1991.

[14] UN - United Nations. Sources and Effects of Ionizing Radiation. UNSCEAR Report to the General Assembly, with annexes. - United Nations, New York, 2010.

[15] Radiological Benchmarks for Screening Contaminants of Potential Concern for Effects on Aquatic Biota at OAK Ridge, Report of the National Laboratory, Oak Ridge, Tennessee. USA, BJC/OR, 1998.

[16] Woodhead, D.S. Contamination due to Radioactive Materials / D.S. Woodhead / In: O. Kinne (ed.), Marine Ecology, Vol. V, Part 3: Pollution and Protection of the Seas-Radioactive Materials, Heavy Metals and Oil. John Wiley and Sons, New York, NY, 1984, pp. 1111-1287.

[17] Kryshev I.I., Sazykina T.G. Simulation models of ecosystem dynamics under the conditions of anthropogenic impact of thermal power plants and nuclear power plants. M.: Energoizdat, 1990, pp. 51-64. (In Russian)

[18] Nosov A.V. and Martynova, A.M. Assessment of secondary pollution of the Yenisei water Atomnaya energiya (Atomic Energy), V. 81, No 3, 1996, pp. 226-232 (in Russian).

[19]. Vakulovsky, S.M., Kryshev, I.I., Nikitin, A.I., Savitsky, Yu.V., Malyshev, S.V., Tertyshnik,E.G., Radioactive contamination of the Yenisei River. $J$. Environ. Radioactivity, V. 29, 1995, pp. 225-236. 


\section{Creative Commons Attribution}

\section{License 4.0 (Attribution 4.0}

International, CC BY 4.0)

This article is published under the terms of the Creative Commons Attribution License 4.0

https://creativecommons.org/licenses/by/4.0/deed.en $\underline{\underline{U S}}$ 